\title{
KESESUAIAN FATWA DSN MUI N0.7/DSN-MUI/IV/2000 DALAM PRODUK PEMBIAYAAN KEPADA KOPERASI UNTUK ANGGOTA (PKPA) DI BANK JATIM SYARIAH CABANG DARMO KOTA SURABAYA'I
}

\author{
Alfina Taswirul Fanni \\ Mahasiswa Program Studi S1 Ekonomi Islam-Fakultas Ekonomi dan Bisnis-Universitas Airlangga \\ Email : alfina.taswirul-11@feb.unair.ac.id
}

Ari Prasetyo

Departemen Ekonomi Syariah-Fakultas Ekonomi dan Bisnis-Unversitas Airlangga Email : ari.prasetyo@feb.unair.ac.id

\begin{abstract}
:
This research purpose is to knowing the conformation of Mudharabah Agreement in the financing mechanism in Syariah Bank Surabaya based on the DSN MUI Decision NO: 07/DSN-MUI/IV/2000Bank Jatim Branch Syariah Darmo Surabaya. This research uses qualitative method with descriptive case study and purposive sampling technique. The data which is used in this research is obtained by semi-structured interview and the data analysis is using descriptive analysis modelThis research indicates that "Bank Jatim Syariah Branch Darmo Surabaya" in performing Mudharabah mechanism are acting in approriate with DSN MUI Decision NO: 07/DSN-MUI/IV/2000 properly. It is indicated with the implementation SOP product with Mudharabah Aggrement which conducted by the regulation of Fatwa DSN MUI NO: 07/DSN-MUI/IV/2000. It starts with the general provisions of Mudharabah Aggrement, pillars and conditions ofMudharabah Aggrement, and law financing of Mudharabah Aggrement. The implementation of this concept has been contributing much benefit to every parties involved.
\end{abstract}

Keywords: Sharia Obedience, Akad Mudharabah, Bank Jatim Syariah Branch Darmo Surabaya

\section{PENDAHULUAN}

\section{Latar Belakang}

Perkembangan Perbankan Syariah diketahui perkembangan beberapa tahun ini meningkat cukup signifikan dengan adanya peraturan undangundang Nomor 10 Tahun 1998 Tentang Perbankan yang memperbolehkan menyediakan pembiayaan dan atau melakukan kegiatan lain berdasarkan Prinsip Syariah, pasar Bank Syariah diramaikannya dengan hadirnnya Bank Umum Syariah dan Bank Konvensional yang mendiversifikasikan bisnisnya dengan memberikan layanan syariah dengan membuka Unit Usaha Syariah, Sementara itu berdasarkan survei BI selama beberapa tahun terakhir ini minat masyarakat terhadap bank syariah di daerah cukup besar. Dalam tiap provinsi yang mayoritas muslim, hampir saparuhnya menghendaki pelayanan perbankan syariah. Sekitar $11 \%$ sudah mengerti produk dan layanan yang ditawarkan. Besarnya kebutuhan layanan syariah di daerah, mendorong sejumlah bank daerah membuka UUS termasuk Bank Pembangunan Daerah Jawa Timur yang mengembangkan usaha dengan membuka UUS di karenakan dorongan masyarakat Provinsi Jawa Timur yang mayoritas beragama muslim, Bank Jatim Selaku Bank Pembangunan Daerah yang ingin memajukan perekonomian

1) Jurnal ini merupakan bagian dari skripsi yang ditulis Alfina Taswirul Fanni. NIM : 041114102 , yang diuji pada 26 mei 2016 
Fanni, et al/Jurnal Ekonomi Syariah Teori dan Terapan Vol. 4 No. 1 Januari 2017: 27-43; KESESUAIAN FATWA DSN MUI N0.7/DSN-MUI/IV/2000 DALAM PRODUK PEMBIAYAAN KEPADA KOPERASI UNTUK ANGGOTA (PKPA) DI BANK JATIM SYARIAH CABANG DARMO KOTA SURABAYA

daerahnya khususnya di Jawa Timur sendiri bersaing dengan Bank-Bank syariah lainnya untuk menarik minat masyarakat dengan adanya layanan syariah yang ditawarkan Bank Jatim dalam Unit Usaha Syariahnya.

Antusiasme masyarakat Indonesia pada layanan syariah ini dapat di ketahui melalui data statistik yang dicatat $\mathrm{Bl}$ dalam (Data Statistik Perbankan Syariah OJK, 2016) tentang komposisi pembiayaan yang dilakukan Bank Umum Syriah maupun Unit Usaha Syariah, menunjukkan perkembangan pembiayaan Bank Syariah di Indonesia pada tahun 2012 sampai 2015 dari seluruh akad yang ditawarkan dalam produk pembiayaan di Bank Umum Syariah maupun Unit Usaha syariah dari keseluruhan mengalami peningkatan. Pembiayaannya antara lain musyarakah, mudharabah, istishna, ijarah, dan salam. Meskipun dapat diketahui bahwa pembiayaan dengan akad murabahah lebih mendominasi dari pada yang lain, dapat diketahui melalui pendapat Idat (2002: 11) yaitu terwujudnya sistem Perbankan Syariah yang kompetitif, efisien, dan memenuhi prinsip kehatihatian yang mampu mendukung sector riil secara nyata melalui kegiatan pembiayaan berbasis bagi hasil dan transaksi riil dalam kerangka keadilan, tolong menolong menuju kebaikan guna mencapai kemaslahatan masyarakat, Hal ini adalah bunyi dari visi Perbankan Syariah

Khususnya akad mudharabah dengan akad kerja samanya untuk menyalurkan dananya secara utuh tanpa potongan apapun dan kerugian di tanggung oleh pihak Bank Syariah yang didalam pelaksanaan akadnya memerlukan prinsip kehati-hatian dan moral hazard yang perlu diperhatikan dengan baik.

Menurut Siddiqi (1985: 9), secara teoritis akad yang paling dikenal oleh masyarakat di dalam perbankan syariah adalah mudharabah (profit and loss sharing). Para penulis Islam modern sepakat menggunakan bentuk kerjasama (musyarakah dan mudharabah) sebagai sarana untuk merekontruksi dan reorganisasi dalam perbankan.Dalam terminologi hukum, mudharabah merupakan kerjasama dalam hubungan bisnis untuk mencari keuntungan.Kerjasama ini dilakukan antara seorang pemilik modal (investor/ shahibul maal) dengan praktis yang memiliki keahlian usaha (mudharib), tentu saja didasari rasa saling amanah, kesepakatan antara kedua belah pihak.Unsur kepercayaan ini menyangkut dua hal, pertama adalah mengenai kualitas personal pelaku usaha. Kedua adalah mengenai kualitas keahlian (profesionalitas) pelaku usaha mengenai usaha bisnis yang akan dilakukan.

Persoalan pertama menyangkut moralitas pelaku usaha (moral hazard). Ini sangat penting didalam mudharabah, karena pemilik modal akan melepaskan dananya di rangan orang lain, yang buka dalam kedudukan sebagau peminjam uang. Jika pelaku usaha tidak mempunyai komitmen 
Fanni, et al/Jurnal Ekonomi Syariah Teori dan Terapan Vol. 4 No. 1 Januari 2017: 27-43; KESESUAIAN FATWA DSN MUI N0.7/DSN-MUI/IV/2000 DALAM PRODUK PEMBIAYAAN KEPADA KOPERASI UNTUK ANGGOTA (PKPA) DI BANK JATIM SYARIAH CABANG DARMO KOTA SURABAYA

moralitas yang kuat, dikhawatirkan akan terjadi penyelewengan atau penyimpangan dana dan atau bahkan penipuan. Sedangkan hal kedua menyangkut masalah skill. Masalah skill ini sangat penting, karena pemilik modal akan memberikan dananya 100 persen kepada pelaku usaha (mudharib), jika mudharib tidak atau kurang mempunyai keahlian dalam bidang usahanya, dikhawatirka akan mengalami kerugian.

Merupakan tantangan tersendiri untuk Bank Jatim Syariah yang dapat di ketahui merupakan Bank hasil pengembangan usaha dari Bank Konvensional apalagi Bank Jatim sendiri beridiri sebagai bank pembangunan daerah Bank Jatim memberanikan diri untuk menawarkan produk pembiayaan dengan prinsip bagi hasil dengan akad mudharabah dengan produk pembiayaan yang ditawarkan dengan prinsip bagi hasil dengan akad mudharabah pada produk PKPA (pembiayaan kepada koperasi untuk anggota). Pembiayaan PKPA (pembiayaan kepada koperasi untuk anggota) ini termasuk ke dalam pembiayaan yang cukup diminati oleh nasabah karena margin bagi hasil yang ditawarkan oleh Bank Jatim Syariah cukup rendah dibandingkan dengan Bank Syariah yang lain yaitu untuk pembiayaan modal kerja dengan akad mudharabah maksimal margin bagi hasil yang dikehendaki pihak Bank Jatim Syariah adalah $13 \%$ dari pendapatan usaha, pemotongan bagi hasil ini dipotong pada pendapatan kotor atau pendapatan bersih suatu usaha sesuai dengan kesepakatan pada awal akad, dan kemudahan dari proses pengajuan sampai pada berakhirnya akad membuat Bank Jatim Syariah Cabang Darmo kota Surabaya ini menjadi pilihan yang diminati oleh nasabah.

Dewan Syariah Nasional (DSN) mengeluarkan fatwa untuk mengatur pelaksanaan akad mudharabah demi mendukung perkembangannya agar sesuai dengan prinsip-prinsip Islam. Hal terebut tertuang dalam fatwa No. 07/ DSN-MUI/ IV/ 2000 yang mengatur tentang ketentuan pembiayaan dengan akad mudharabah, rukun dan syarat pembiayaan dengan akad mudharabah, serta ketentuan hukum pembiayaan dengan akad mudharabah, dalam fatwa ini dijelaskan ditiap butirnya mengenai akad mudharabah, prosedur, sampai penyelasaian masalah jika terjadi perselisihan

Kepatuhan syariah merupakan pilar penting dalam pengembangan lembaga syariah.Yaitu merupakan pembeda antara lembaga keuangan syariah dengan lembaga keuangan konvensional.(Ikatan Bankir Indonesia, 2014: 358) menyampaikan bahwa kepatuhan syariah merupakan suatu hal yang tidak dapat diabaikan pada suatu lembaga keuangan, terlebih pada lembaga keuangan syariah.Kepatuhan syariah dapat menjadikan reputasi sebuah lembaga keuangan syariah baik apabila dilaksanakan dengan benar dan 
Fanni, et al/Jurnal Ekonomi Syariah Teori dan Terapan Vol. 4 No. 1 Januari 2017: 27-43; KESESUAIAN FATWA DSN MUI N0.7/DSN-MUI/IV/2000 DALAM PRODUK PEMBIAYAAN KEPADA KOPERASI UNTUK ANGGOTA (PKPA) DI BANK JATIM SYARIAH CABANG DARMO KOTA SURABAYA

sesuai dengan aturan yang ada.Oleh karena itu, Ototitas Jasa Keuangan (2011) menyatakan penting untuk dilakukan pengawasan fungsi kepatuhan syariah di industri keuangan syariah, dimana fungsi kepatuhan merupakan tindakan dan langkah yang bersifat ex-ante (preventif), untuk memastikan kebijakan, ketentuan, sistem dan prosedur, serta kegiatan usaha yang dilakukan oleh Bank Islam sesuai dengan ketentuan Bank Indonesia, fatwa DSN dan peraturan perundang-undangan yang berlaku. Hal ini dilakukan untuk mengontrol operasional perbankan syariah serta menjadikan bank syariah agar tidak keluar dari koridornya, disiplin dan langkah untuk meminimalisir resiko perbankan.

Penelitian ini bertujuan untuk mengetahui terpenuhinya kepatuhan syariah akad mudharabah dalam produk pembiayaan kepada koperasi pada anggota (PKPA) berdasarkan Fatwa DSN MUI No. 07/DSN-MU/IV/2000 di Bank Jatim Syariah dalam melaksanakan kegiatannya sebagai lembaga keuangan dan lembaga intermediasi. Hasil penelitian diharapkan bermanfaat bagi perbank syariah, yaitu dapat meningkatnya kesadarannya mengenai terpenuhinya kepatuhan syariah akad mudharabah dalam produk pembiayaan kepada koperasi pada anggota (PKPA). sedangkan manfaat bagi masyarakat adalah dapat mengetahui Bank Jatim Syariah apakah sudah melaksanakan mekanismpe pembiayaan akad mudharabah sesuai dengan ketetapan syariah sehingga menghasilkan kulaitas pembiayaan akad mudharabah yang bermutu dan masyarakat atau nasabah dapat menaruh kepercayaan dan rasa aman yang lebih pada bank syariah yang sudah digunakannya maupun masyarakat atau nasabah yang baru akan membuka rekening atau melakukan pembiayaan di perbankan syariah.

\section{TINJAUAN PUSTAKA}

Perbankan Syariah menurut Undang-Undang Perbankan Syariah No. 21 tahun 2008 pasal 1 adalah segala sesuatu yang menyangkut tentang Bank Syariah dan Unit Usaha Syariah, Mencakup kelembagaan, kegiatan usaha, serta cara dan proses dalam melaksanakan kegiatan usahanya. Bank Syariah adalah Bank yang menjalankan kegiatan usahanya berdasarkan Prinsip Syariah dan menurut jenisnya terdiri atas Bank Umum Syariah dan Bank Pembiayaan Rakyat Syariah.

Sebagai lembaga keuangan, bank memiliki fungsi sebagai lembaga intermediasi. Muhammad (2006: 36) menyatakan, bank syariah menjalankan fungsinya sebagai lembaga keuangan yang berlandaskan pada syariah. Fungsi bank syariah adalah sebagai berikut :

1. Bank sebagai manajer investasi

2. Bank sebagai investor

3. Bank sebagai pemberi jasa keuangan

4. Bank sebagai agen sosial

Lebih lanjut menurut Heri Sudarsono di dalam Bank Dan Lembaga Keuangan Syariah, (2008:43-44) bank 
Fanni, et al/Jurnal Ekonomi Syariah Teori dan Terapan Vol. 4 No. 1 Januari 2017: 27-43; KESESUAIAN FATWA DSN MUI N0.7/DSN-MUI/IV/2000 DALAM PRODUK PEMBIAYAAN KEPADA KOPERASI UNTUK ANGGOTA (PKPA) DI BANK JATIM SYARIAH CABANG DARMO KOTA SURABAYA

syariah memiliki beberapa tujuan di antaranya sebagai berikut:

1. Mengarahkan kegiatan ekonomi umat untuk ber-muamalat secara Islam.

2. Untuk menciptakan suatu keadilan di bidang ekonomi dengan jalan meratakan pendapatan melalui kegiatan investasi.

3. Untuk meningkatkan kualitas hidup umat dengan jalan membuka peluang usaha.

4. Untuk menanggulangi masalah kemiskinan.

5. Untuk menyelamatkan ketergantungan umat Islam terhadap bank non- syariah.

Muhammad (2006: 56) juga menjelaskan, setiap lembaga keuangan syariah mempunyai falsafah untuk mencari keridhoan Allah SWT untuk memperoleh kebahagiaan di dunia akhirat. Oleh karena itu, setiap kegiatan kevangan yang di khawatirkan menyimpang dari tuntunan Islam harus dihindari. Hal-hal yang harus dihindari di antaranya adalah :

1. Riba

2. Penggunaan sistem yang bukan berdasar bagi hasil dan perdagangan.

Secara definitif profit sharing diartikan: "distribusi beberapa bagian dari laba pada para pegawai dari suatu perusahaan" . Pada perbankan syariah sistem bagi hasil ini diterapkan pada produk pembiayaan baik untuk modal kerja ataupun investasi. Akad yang biasa digunakan dalam pembiayaan ini adalah akad syirkah yang dapat dibagi lagi menjadi akad mudharabah dan musyarakah. Karim (2010: 286) menjelaskan bahwa terdapat beberapa pertimbangan dalam menentukan nisbah bagi hasil. Beberapa pertimbangan penetapan nisbah bagi hasil adalah referensi tingkat keuntungan serta perkiraan tingkat keuntungan yang dibiayai.

Nafik (2008; 171) menyatakan terdapat empat model perhitungan nisbah bagi hasil:

1. Revenue sharing

2. Gross profit sharing system

3. Operating profit sharing system

4. Net profit sharing system

$$
\text { Muhammad (2006: }
$$

menyatakan bahwa pembiayaan berdasarkan prinsip syariah menurut Undang-Undang Nomor 10 Tahun 1998 tentang perbankan adalah Penyediaan vang atau tagihan yang dipersamakan dengan itu berdasarkan persetujuan atau kesepakatan antara bank dengan pihak lain yang mewajibkan pihak yang dibiayai untuk mengembalikan uang atau tagihan tersebut setelah jangka waktu tetentu dengan imbalan atau bagi hasil.

Adapun unsur-unsur pembiayaan syariah menurut Sabiq (1998: 178) adalah sebagai berikut :

1) Tidak menyalahi hukum syariah yang disepakati adanya.

2) Terjadinya perjanjian atas dasar saling ridho dan ada pilihan, dalam hal ini 
Fanni, et al/Jurnal Ekonomi Syariah Teori dan Terapan Vol. 4 No. 1 Januari 2017: 27-43; KESESUAIAN FATWA DSN MUI N0.7/DSN-MUI/IV/2000 DALAM PRODUK PEMBIAYAAN KEPADA KOPERASI UNTUK ANGGOTA (PKPA) DI BANK JATIM SYARIAH CABANG DARMO KOTA SURABAYA

tidak boleh ada unsur paksaan dalam membuat perjanjian tersebut.

3) Isi perjanjian harus jelas dan gamblang.

Adapun jenis-jenis pembiayaan menurut Antonio (2001:168) adalah sebagai berikut :

a. Pembiayaan Produktif

1) Pembiayaan modal kerja

2) Pembiayaan Investasi

b. Pembiayaan Konsumtif

Menurut Kasmir (2005: 104-105) dalam melakukan penilaian kriteria-kriteria serta aspek penilaiannya tetap sama. Begitu pula dengan ukuran-ukuran yang ditetapkan sudah menjadi standar penilaian setiap bank. Biasanya kriteria penilaian yang harus dilakukan oleh bank untuk mendapatkan nasabah yang benar-benar menguntungkan dilakukan dengan analisis 5C dan 7P. Adapun penjelasan untuk $5 \mathrm{C}$ sebagai berikut:

a. Character (Karakter)

b. Capacity (Kemampuan)

c. Capital (Modal Sendiri)

d. Colleteral (Jaminan)

e. Condition (Kondisi)

Kemudian penilaian pembiayaan dengan metode analisis 7P menurut Kasmir (2005: 106-107) adalahPersonality, Party, Perpose, Prospect, Payment, Profitability, dan Protection.

Pengertian Mudharabah sendiri disampaikan oleh Antonio (2001: 97) ada dua pengertian. Yaitu mudharabah dan giradh sesuai dengan penggunaannya di kalangan kaum muslimin. Disebut sebagai mudharabah, karena diambil dari kata dharb di muka bumi. Yang artinya, melakukan perjalanan yang umumnya untuk berniaga dan berperang. Allah berfirman (Al-Muzzammil (73): 20), bahwa Mudharabah merupakan akad kerja sama usaha antara dua belah pihak dimana pihak pertama (shahibul mal) menyediakan seluruh (100\%) modal, sedangkan pihak lain sebagi pengelola. Keuntungan usaha secara mudharabah dibagai menurut kesepakatan yang dituangkan di dalam kontrak, sedangkan apabila rugi ditanggung oleh pemilik modal selama kerugian itu bukan akibat kelalaian si pengelola. Seandainnya kerugian itu diakibatkan karena kecurangan atau kelalaian si pengelola, sipengelola harus bertanggung jawab atas kerugian tersebut.

Secara umum mudharabah terbagi menjadi dua jenis yaitu (Sudarsono, 2005: 59-60) :

a. Mudharabah Muthlaqah

b. Mudharabah Muqayyadah (restricted mudharabah atau speciefied mudharabah)

Dewan Syariah Nasional Majelis Ulama Indonesia telah menyiapkan serangkaian fatwa yang harus dipakai sebagai landasan operasional Lembaga Keuangan Islam dalam melayani jasa dibidang mudharabah. Pedoman tersebut tertuang dalam sekumpulan fatwa DSN MUI tentang mudharabah yaitu FATWA DEWAN SYARI'AH NASIONAL NO: 07/DSN$\mathrm{MUI} / \mathrm{IV} / 2000$.

Untuk mengkaji seluruh ketentuan syariah dalam persoalan-persoalan 
Fanni, et al/Jurnal Ekonomi Syariah Teori dan Terapan Vol. 4 No. 1 Januari 2017: 27-43; KESESUAIAN FATWA DSN MUI N0.7/DSN-MUI/IV/2000 DALAM PRODUK PEMBIAYAAN KEPADA KOPERASI UNTUK ANGGOTA (PKPA) DI BANK JATIM SYARIAH CABANG DARMO KOTA SURABAYA

mudharabah, persoalan-persoalan mudharabah disajikan dalam tiga butir ketentuan, yaitu :

a. Butir pertama tentang ketentuan umum pembiayaan mudharabah (Qiradh)

b. Butir kedua tentang rukun dan syarat pembiayaan mudharabah (Qiradh)

c. Butir ketiga tentang ketentuan hukum pembiayaan Mudharabah (Qiradh)

Antonio (2001: 98) Pembiayaan mudharabah yang dilakukan di lembaga keuangan syariah, seperti Bank, BPRS, BMT memiliki ciri-ciri yang sama, yaitu :

1. Nisbah bagi hasil harus ditentukan dan disetujui oleh pihak lembaga kevangan dan nasabah di awal perjanjian.

2. Hubungan antara shahibul mal dengan mudharib adalah merupakan hubungan mitra.

3. Obyek (proyek yang akan dibiayai) yang diperjanjikan dicantumkam dalam aqad.

4. Memakai prinsip bagi hasil, tepatnya profit sharing.

5. Perjanjian/akad mudharabah, yaitu dana seutuhnya berasal dari si shahibul maal (lembaga keuangan) dan bagi hasil dilakukan berdasarkan kesepakatan.

6. Saling percaya (kepercayaan yang tinggi) antara kedua belah pihak.

Mekanisme Kepatuhan Syariah ada dua konsep yang mendasari pelaksanaan pengawasannya secara internal dalam bank syariah dalam konteks pemenuhan akuntabilitas secara horizontal dan transedental. Yang pertama adalah konsep sharia review yang harus dilakukan oleh dewan pengawas syariah untuk melakukan pengawasan kepatuhan syariah, dan yang kedua adalah konsep internal sharia review dalam bank syariah sebagai salah satu fungsi internal audit dalam bank syariah untuk menilai kesesuaian operasi dan transaksi dengan prinsip-prinsip syariah yang telah ditentukan.

Dalam menjalankan tanggung jawabnya, pengawas bank selain memenuhi prinsip-prinsip profesionalisme juga semestinya memiliki suatu keyakinan bahwa Allah senantiasa mengawasi (faithdriven conduct atau Waskat). Menurut nilai-nilai Islami unsur profesionalisme pengawas bank syariah terdiri dari sifat siddiq (jujur), tabligh (menyampaikan kebenaran dan senatiasa membina), amanah (bertanggung jawab), dan fathonah (memiliki skill dan pengetahuan yang mumpuni) yang dapat disingkat STAF.

Nilai-nilai islami yang pada dasarnya mendorong akuntabititas antara lain adalah:

a. Ma'iyatullah dan muraqabah

b. Muhasabah

C. Mas'uliyah

Menurut Gandapradja

(2004) Dewan Pengawas Syariah (DPS) : Haiah alMuraqabah as-Syariah Adalah Dewan yang keanggotaannya direkomendasikan oleh Dewan Syariah Nasional dan ditempatkan pada Bank yang melakukan Kegiatan Usaha Berdasarkan prinsip 
Fanni, et al/Jurnal Ekonomi Syariah Teori dan Terapan Vol. 4 No. 1 Januari 2017: 27-43; KESESUAIAN FATWA DSN MUI N0.7/DSN-MUI/IV/2000 DALAM PRODUK PEMBIAYAAN KEPADA KOPERASI UNTUK ANGGOTA (PKPA) DI BANK JATIM SYARIAH CABANG DARMO KOTA SURABAYA

syariah, dengan tugas dan kewenangan yang diatur oleh Dewan Syariah Nasional. DPS melakukan pengawasan terhadap penerapan prinsip syariah dalam lembaga keuangan syariah.

Fungsi DPSpada masing-masing lembaga kevangan syariah adalah sebagai berikut:

a. melakukan pengawasan secara periodik pada LKS yang berada di bawah pengawasannya;

b. berkewajiban mengajukan usul-usul pengembangan LKS kepada pimpinan lembaga yang bersangkutan dan kepada DSN;

c. melaporkan perkembangan produk dan operasional LKS yang diawasinya kepada DSN sekurang-kurangnya 2 (dua) kali dalam 1 (satu) tahun anggaran;

d. merumuskan permasalahanpermasalahan yang memerlukan pembahasan DSN.

Berdasarkan landasan teori yang telah dijelaskan, maka dapat dirancang

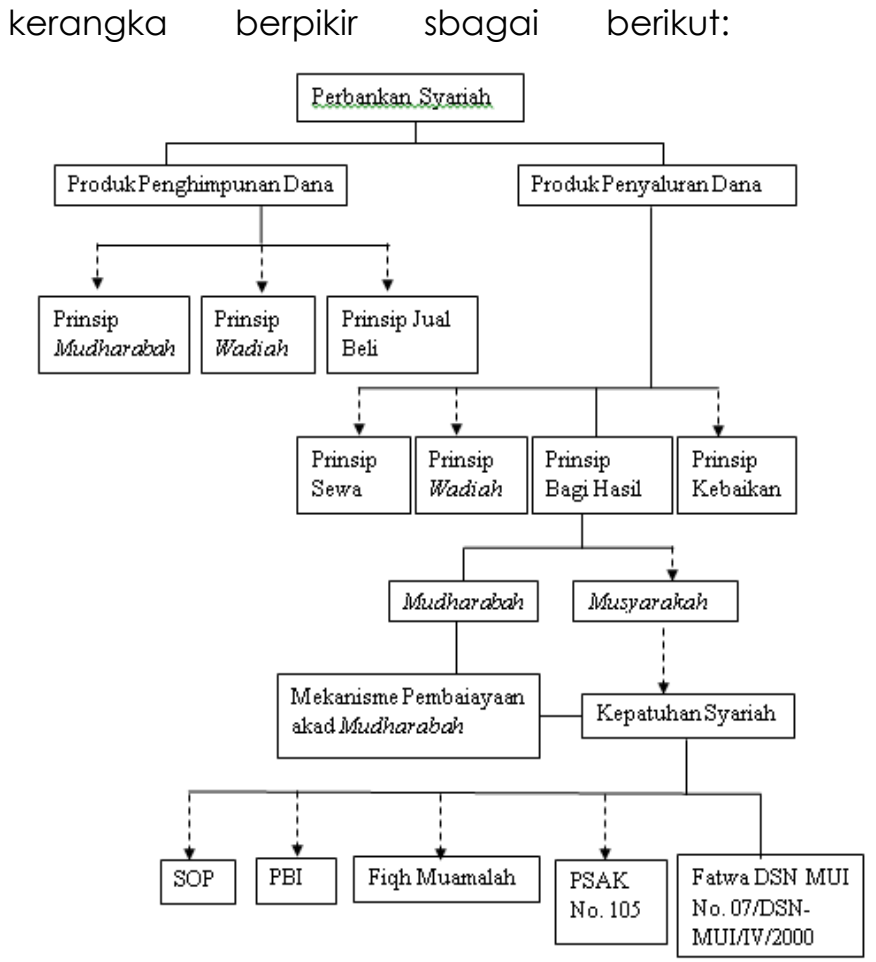

Gambar 1. Kerangka Berpikir

\section{METODE PENELITIAN}

\section{Pendekatan Penelitian}

Penelitian ini menggunakan pendekatan penelitian kualitatif.Menurut Yin $(2009 ; 2)$ pendekatan kualitatif adalah pendekatan dengan menggunakan data yang berupa kalimat tertulis atau lisan, peristiwa-peristiwa, pengetahuan yang bersifat deskriptif.

\section{Ruang Lingkup Penelitian}

Rumusan masalah yang merupakan fokus studi dalam sebuah penelitian kualitatif menjadi acuan dalam menentukan ruang lingkup penelitian. Pemenuhan kepatuhan syariah akad mudharabah dalam produk pembiayaan kepada koperasi untuk anggota (PKPA) berdasarkan Fatwa DSN MUI No. 07/DSNMUI/IV/2000 di Bank Jatim Syariah Cabang Darmo Kota Surabaya 
Fanni, et al/Jurnal Ekonomi Syariah Teori dan Terapan Vol. 4 No. 1 Januari 2017: 27-43; KESESUAIAN FATWA DSN MUI N0.7/DSN-MUI/IV/2000 DALAM PRODUK PEMBIAYAAN KEPADA KOPERASI UNTUK ANGGOTA (PKPA) DI BANK JATIM SYARIAH CABANG DARMO KOTA SURABAYA

\section{Jenis dan Sumber Data}

Data yang dihimpun oleh penulis terdiri atas data primer dan data sekunder. Data primer diperoleh dari wawancara dengan pihak Bank Jatim Syariah Cabang Darmo Surabaya yang bertanggung jawab atas pembiayaan, dewan pengawas syariah dalam Bank Jatim Syariah Cabang Darmo Surabaya, dan pihak nasabah yang menggunakan pembiayaan dengan akad mudharabah. Serta wawancara dengan pihak DSN MUI. Data sekunder diperoleh dari dokumendokumen yang diperoleh dari Bank Jatim Syariah Cabang Darmo Surabaya tentang produk pembiayaan dengan akad mudharabah.

\section{Prosedur Pengumpulan Data}

Yin (2009:1 14-123) menjelaskan tiga prinsip dalam melakukan pengumpulan data, yaitu:

1. Menggunakan Multisumber Bukti

Terdapat dua hal yang perlu diperhatikan dalam menggunakan multisumber bukti, yaitu:

a. Triangulation.

b. Prerequisites for using multiple sources of evidence.

2. Mengumpulkan Database

3. Menjaga Keberadaan Rantai Bukti

Adapun prosedur pengumpulan data dalam penelitian ini adalah sebagai berikut :

a. Persiapan awal

b. Proses saat di lokasi atau obyek penelitian

c. Saat Pengumpulan data

\section{Teknik Keabsahan Data}

Yin (2009:38) menjelaskan suatu desain penelitian mengetengahkan serangkaian pertanyaan logis, maka dapat menetapkan kualitas desain menurut uji logika tertentu. Dalam menetapkan kualitas tersebut terdapat empat uji, yaitu:

1. Validitas konstruk

2. Validitas internal

3. Validitas eksternal

4. Realibilitas

\section{Teknik Analisis Data}

Teknik analisis yang digunakan dalam penelitian ini menggunakan teori milik Miles dan Huberman (1992) dalam buku Yin, yang menjelaskan ada tiga proses yaitu:

1. Data Reduction (Reduksi Data)

2. Data Display (Penyajian Data

3. Conclusion Drawing/Verification

(Menarik Kesimpulan/ Verivfkasi

Peneliti menggunakan teknik analisis penjodohan pola dalam penelitian ini di ungkapkan oleh Yin (2009: 140), logika penjodohan pola adalah membandingkan pola yang didasarkan atas empiris dengan pola yang diprediksikan. Pola tersebut berdasarkan teori empiris yang telah dikemukakan pada bab 2 dan berdasarkan proposisi yang telah disusun terkait dengan bagaimana kepatuhan syariah akad mudharabah dalam pembiayaan kepada koperasi untuk anggota di Bank Jatim Syariah Cabang Darmo Kota Surabaya berdasarkan Fatwa Dewan Syariah Nasional Majelis Ulama Indonesia 
Fanni, et al/Jurnal Ekonomi Syariah Teori dan Terapan Vol. 4 No. 1 Januari 2017: 27-43; KESESUAIAN FATWA DSN MUI N0.7/DSN-MUI/IV/2000 DALAM PRODUK PEMBIAYAAN KEPADA KOPERASI UNTUK ANGGOTA (PKPA) DI BANK JATIM SYARIAH CABANG DARMO KOTA SURABAYA

\section{HASIL DAN PEMBAHASAN}

Produk Pembiayaan Kepada Koperasi Untuk Anggota (PKPA) Menggunakan

\section{Akad Mudharabahdi Bank Jatim Syariah}

Informan menyampaikan konsep pembiayaan dengan akad mudharabah sesuai dengan teori yang disampaikan oleh Antonio (2001) bahwa mudharabah adalah akad kerja sama usaha antara dua belah pihak dimana pihak pertama (shahibul mal) menyediakan seluruh (100\%) modal, sedangkan pihak lain sebagi pengelola. Keuntungan usaha secara mudharabah dibagai menurut kesepakatan yang dituangkan di dalam kontrak, sedangkan apabila rugi ditanggung oleh pemilik modal selama kerugian itu bukan akibat kelalaian si pengelola. Seandainya kerugian itu diakibatkan karena kecurangan ataukelalaian si pengelola, si pengelola harus bertanggung jawab atas kerugian tersebut.

Bank Jatim Syariah sebagai lembaga keuangan yang terpercaya berusaha membangun karakter Sumber Daya Insani (SDI) dengan prinsip luhur yang dicontohkan oleh Rasulullah SAW yaitu insan BJS yang beriman, cerdas, amanah, jujur, berkomunikasi dengan baik. Pribadi demikian diharapkan akan memiliki empati, edifikasi, dan berorientasi hasil yang sepenuhnya mengutamakan layanan fokus kepada nasabah. Keadaan ekonomi Indonesia sampai sekarang masih memperihatinkan. Dalam Sistem Ekonomi Syariah, ada landasan etika dan moral dalam melaksanakan semua kegiatan termasuk kegiatan ekonomi, selain harus adanya keseimbangan antara peran pemerintah, swasta, kepentingan dunia dan kepentingan akhirat. Penelitian bertujuan untuk mengetahui perkembangan Bank Jatim Syariah Cabang Darmo Surabaya dalam mensukseskan visi dan misi organisasinya. informan diketahui bahwa perkembangan Bank Jatim Syariah Cabang Darmo Surabaya menerima respon yang baik dari masyarakat dengan bukti laporan keuangan yang diterbitkan OJK (Otoritas jasa Keuangan) yang semakin meningkat dari tahun ke tahun. Menurut Ascarya (2009:4) sebagai lembaga keuangan yang menggunakan sistem syariah, maka bank harus mentaati prinsip-prinsip syariah yang telah ditetapkan. Prinsip-prinsip dasar perbankan syariah meniadakan riba dalam bentuk transaksi apapun, melakukan kegiatan bisnis atau usaha yang berlandaskan kepada prinsip keadilan dan keuntungan yang halal, menyalurkan zakat, melarang monopoli, melakukan kerjasama untuk mencapai manfaat bagu masyarakat dan mengembangkan seluruh aspek kehalalan didalam bisnis dan investasi yang tidak dilarang oleh syariat Islam, sehingga Bank Jatim Syariah merupakan salah satu lembaga syariah harus semaksimal mungkin menerapkan prinsip syariah yang meskipun dalam pelaksanaannya masih terkendala banyak hal. Salah satu produk 
Fanni, et al/Jurnal Ekonomi Syariah Teori dan Terapan Vol. 4 No. 1 Januari 2017: 27-43; KESESUAIAN FATWA DSN MUI N0.7/DSN-MUI/IV/2000 DALAM PRODUK PEMBIAYAAN KEPADA KOPERASI UNTUK ANGGOTA (PKPA) DI BANK JATIM SYARIAH CABANG DARMO KOTA SURABAYA

pembiayaannya menggunakan akad mudharabahadalah produk Pembiayaan Kepada Koperasi untuk Anggota (PKPA) adalah pembiayaan Modal Kerja yang diberikan Bank kepada Koperasi baik Koperasi Primer maupun Koperasi Sekunder untuk disalurkan kepada aggotanya dengan pola Line Facility dan pencairan bertahap.

PKPA bertujuan untuk meningkatkan peranan koperasi dalam meningkatkan kesejahteraan anggotanya dan masyarakat pada umumnya serta ikut membangun tatanan perekonomian sosial, meningkatkan peranan Bank dalam penyaluran pembiayaan kepada koperasi, dan meningkatkan portofolio pembiayaan, Pembiayaan ini menggunakan akad mudharabah karena merupakan pembiayaan modal kerja atau produltif.

\section{Ketentuan Pembiayaan Dengan Akad} Mudharabah

Hasil analisis menunjukkan mudharobah merupakan akad untuk pembiayaan dengan sistem bagi hasil yang diberikan untuk jenis pembiayaan produktif, bukan konsumtif. Pernyataan tersebut sesuai dengan definisi pada Fatwa Dewan Syariah Nasional MUI bahwa pembiayaan mudharobah adalah pembiayaan yang disalurkan oleh LKS kepada pihak lain untuk suatu usaha yang produktif. Menurut Antonio (2001:168) pembiayaan produktif adalah pembiayaan yang ditujukan untuk memenuhi kebutuhan produksi dalam arti luas yaitu untuk peningkatan usaha baik usaha produksi, perdagangan maupun investasi. Bank Jatim Syariah dengan produk pembiayaan yang ditawarkan dengan prinsip bagi hasil yaitu PKPA (pembiayaan koperasi pada anggota).

Prinsip pembiayaan dengan akad mudharabah tidak ada potongan sama sekali, artinya pengguna dana menerima $100 \%$ utuh sesuai dengan yang tertera pada akad perjanjian, sedangkan untuk biaya lain-lain seperti administrasi, biaya notaris, materai dibayarkan secara terpisah. Hal tersebut dijalankan oleh Bank Jatim Syariah sesuai dengan Fatwa Dewan Syariah Nasional MUI dimana menyatakan bahwa dalam pembiayaan ini LKS sebagai shahibul maal (pemilik dana) membiayai 100\% kebutuhan suatu proyek (usaha), sedangkan pengusaha (nasabah) bertindak sebagai mudharib atau pengelola usaha.

Kedua belah pihak baik pemilik dana maupun pengguna dana juga diharuskan memahami dan mengerti isi dari perjanjian yang akan disepakati. Hal tersebut sesuai dengan Fatwa yang ditentukan oleh Dewan Syariah Nasional MUI bahwa jangka waktu usaha, tatacara pengembalian dana, dan pembagian keuntungan ditentukan berdasarkan kesepakatan kedua belah pihak (LKS dengan pengusaha), sedangkan dari pihak Dewan Syariah Nasional MUI hanya melakukan pengawasan dari segi kontrol laporan keuangannya.

Pengawasan yang dilakukan oleh pihak bank kepada pengguna dana dilakukan dengan cara melakukan audit 
Fanni, et al/Jurnal Ekonomi Syariah Teori dan Terapan Vol. 4 No. 1 Januari 2017: 27-43; KESESUAIAN FATWA DSN MUI N0.7/DSN-MUI/IV/2000 DALAM PRODUK PEMBIAYAAN KEPADA KOPERASI UNTUK ANGGOTA (PKPA) DI BANK JATIM SYARIAH CABANG DARMO KOTA SURABAYA

pada laporan keuangan mereka selama dua bulan sekali, sedangkan untuk pengajuan pembiayaan baru pihak bank akan menseleksi calon nasabahnya dengan menerapkan kualifikasi dan persyaratan tertentu, apabila pihak bank menilai calon nasabah tersebut meragukan maka pihak bank tidak akan meloloskannya. Salah satu persyaratan dalam perjanjian tersebut adalah jenis usaha yang akan dikelola oleh pengguna dana harus sesuai dengan syariah, karena sesuai dengan prinsip bank syariah bahwa akan menjalankan segala sesuatunya dengan prinsip-prinsip syariah, sesuai dengan Al-Qur'an dan Al-Hadist.

Pihak Bank wajib mengetahui jenis usaha yang dikelola oleh calon nasabah selaku pengelola dana, hal tersebut dikarenakan sesuai dengan prinsip bank syariah yang dalam tata maupun pengelolaannya harus sesuai dengan syariah. Selain persyaratan dalam jenis usaha yang harus sesuai dengan syariah, persyaratan lainnya yaitu dana yang diberikan kepada pihak pengelola (mudharib) diharuskan dalam bentuk tunai.

Dana yang diberikan pihak bank kepada nasabah dalam hal ini adalah pengelola dana (mudharib) adalah berupa dana tunai. Pernyataan tersebut membuktikan bahwa pihak Bank Jatim Syariah telah menjalankan sesuai dengan ketentuan yang berlaku yaitu Fatwa Dewan Syariah Nasional MUI yang berbunyi bahwa jumlah dana pembiayaan harus dinyatakan dengan jelas dalam bentuk tunai dan bukan piutang.

Pengguna dana memahami apabila mengalami kerugian, maka $100 \%$ menjadi tanggung jawab pihak pemilik dana (shahibul maal). Hal tersebut sesuai dengan teori yang dikemukakan oleh Antonio bahwa keuntungan usaha secara mudharabah dibagai menurut kesepakatan yang dituangkan di dalam kontrak, sedangkan apabila rugi ditanggung oleh pemilik modal selama kerugian itu bukan akibat kelalaian si pengelola, namun seandainnya kerugian itu diakibatkan karena kecurangan atau kelalaian si pengelola, si pengelola harus bertanggung jawab atas kerugian tersebut. Artinya pihak Bank Jatim Syariah sudah melakukan kebijakan yang sesuai dengan Fatwa Dewan Syariah Nasional MUI dimana LKS sebagai penyedia dana menanggung semua kerugian akibat dari mudharabah kecuali jika mudharib (nasabah) melakukan kesalahan yang disengaja, lalai, atau menyalahi perjanjian. Sesuai dengan teori delegated monitoring yang disebutkan oleh Allen (2010), nasabah dan masyarakat pada umumnya tidak dapat dengan mudah melakukan monitoring dan pengawasan bank. Alasannya antara lain karena kurangnya kompetensi dan kemampuan, kesulitan untuk mengakses informasi tentang kinerja bank, serta tidak tersedianya waktu dan adanya masalah efisiensi untuk dapat melaksanakan pengawasan terhadap kegiatan usaha bank 
Fanni, et al/Jurnal Ekonomi Syariah Teori dan Terapan Vol. 4 No. 1 Januari 2017: 27-43; KESESUAIAN FATWA DSN MUI N0.7/DSN-MUI/IV/2000 DALAM PRODUK PEMBIAYAAN KEPADA KOPERASI UNTUK ANGGOTA (PKPA) DI BANK JATIM SYARIAH CABANG DARMO KOTA SURABAYA

Setiap pembiayaan produktif dengan akad mudharabah diwajibkan menggunakan jaminan. Seperti penjelasan MUI dalam fatwanya dimana dalam pembiayaan mudharabah tidak ada jaminan, namun agar mudharib tidak melakukan penyimpangan, LKS dapat meminta jaminan dari mudharib atau pihak ketiga. Jaminan ini hanya dapat dicairkan apabila mudharib terbukti melakukan pelanggaran terhadap hal-hal yang telah disepakati bersama dalam akad. Secara prinsip dalam konsep mudharabah tidak ada jaminan yang diambil sebagai agunan dan Jaminan dapat diambil untuk menjaga agar nasabah benar-benar melaksanakan usaha dengan baik. Dalam incentive compatible constraints pene-tapan agunan berupa aset tetapakan mencegah mudharib melakukan penyelewengan karena jaminan yang sudah diberikannya itu menjadi harga dari penyelewengan atas perilakunya (character risk). Hasil tersebut didukung oleh kesimpulan dari penelitian Yudha (2010) dimanaperbankan syariah di wilayah Surabaya memiliki nasabah yang karakternya bermacam-macam dan sedemikian terbuka menjadikan bank syariah sebagai penyedia pembiayaan tidak mampu mengetahui keadaan calon nasabah yang akan dibiayai dengan mudharabah yang nilainya terbatas, hal tersebut yang menyebabkan bank syariah perlu meminta jaminan dalam pembiayaan mudharabah.
Pihak Bank Jatim Syariah juga selalu melakukan crosscek setiap bulan karena dikhawatirkan ada penyimpangan yang terjadi sehingga mengakibatkan keluarnya dari kaidah yang sudah ditetapkan oleh DSN, dalam hal ini pihak OJK akan memberikan teguran apabila terbukti pihak bank melakukan penyimpangan. Hal tersebut sesuai dengan peraturan Otoritas Jasa Keuangan (2011) yang menyatakan bahwa pengawasan yang dilakukan $\mathrm{BI}$ meliputi pengawasan langsung dan tidak langsung. Bl mewajibkan bank untuk menyampaikan laporan, keterangan, dan penjelasan sesuai dengan tata cara yang ditetapkan BI. BI melakukan pemeriksaan terhadap bank, baik secara berkala maupun setiap waktu apabila diperlukan. BI dapat memerintahkan bank untuk menghentikan sementara sebagian atau seluruh kegiatan transaksi tertentu apabila menurut penilaian $\mathrm{Bl}$ transaksi tersebut diduga merupakan tindak pidana di bidang perbankan, sehingga membahayakan sistem perbankan dan perekonomian nasional.

\section{Rukun dan Syarat Akad Mudharabah}

Melakukan akadmudharabah dengan mengacu pada kesepakatan dari kedua belah pihak dikatakan sah secara hukum maupun agama jika memenuhi syarat-syarat dan rukunnya. Informan terlihat sudah memahami hukum dengan baik, untuk membuktikan bahwa kedua belah pihak cakap hukum perjanjian dilakukan dihadapan Notaris, dengan kata lain pihak Notaris akan 
Fanni, et al/Jurnal Ekonomi Syariah Teori dan Terapan Vol. 4 No. 1 Januari 2017: 27-43; KESESUAIAN FATWA DSN MUI N0.7/DSN-MUI/IV/2000 DALAM PRODUK PEMBIAYAAN KEPADA KOPERASI UNTUK ANGGOTA (PKPA) DI BANK JATIM SYARIAH CABANG DARMO KOTA SURABAYA

menilai kecakapan dari kedua belah pihak yang melakukan perjanjian, dimana hal tersebut sesuai dengan Fatwa Dewan Syariah Nasional MUI yang menyebutkan bahwa Penyedia dana (sahibul maal) dan pengelola (mudharib) harus cakap hukum. Perjanjian pembiayaan mudharabah dapat dilakukan jika sesuai dengan kaidah yang ditetapkan dalam syariah.

modal yang diberikan oleh pihak Bank Jatim Syariah kepada pengelola dana pada saat akad berlangsung adalah modal tunai, bukan modal piutang namun pemberiaannya bisa secara langsung ataupun bertahap, hal tersebut sesuai dengan ketentuan Fatwa Dewan Syariah Nasional MUI yang menyebutkan bahwa modal ialah sejumlah vang atau aset yang diberikan olehpenyedia dana kepada mudharib untuk tujuan usaha dengan syarat sebagai berikut: (a) Modal harus diketahui jumlah dan jenisnya. (b) Modal dapat berbentuk uang atau barang yang dinilai, jika modal diberikan dalam bentuk aset, maka aset tersebut harus dinilai pada waktu akad. (c) Modal tidak dapat berbentuk piutang dan harus dibayarkankepada mudharib, baik secara bertahap maupun tidak, sesuaidengan kesepakatan dalam akad. Ketentuan berikutnya adalah mengenai proporsi bagi hasil keuntungan antara kedua belah pihak yang melakukan perjanjian.

Pembagian hasil keuntungan dari akad mudharabah yang dilakukan oleh pihak pemilik dana (shahibul maal) dan pengelola dana (mudharib) disesuaikan dengan akad yang telah disepakati sebelumnya, yang nilai porsinya ditentukan sendiri oleh kedua belah pihak, sehingga dengan kata lain pihak Bank Jatim Syariah telah menjalankan prinsip syariah yang dimana telah diatur dalam Fatwa Dewan Syariah MUI sebagai berikut: keuntungan mudharabah adalah jumlah yang didapat sebagai kelebihan dari modal. Syarat keuntungan berikut ini harus dipenuhi: (a) Harus diperuntukkan bagi kedua pihak dan tidak boleh disyaratkan hanya untuk satu pihak. (b) Bagian keuntungan proporsional bagi setiap pihak harus diketahui dan dinyatakan pada waktu kontrak disepakati dan harus dalam bentuk prosentasi (nisbah) dari keuntungan sesuai kesepakatan, perubahan nisbah harus berdasarkan kesepakatan. (c) Penyedia dana menanggung semua kerugian akibat dari mudharabah, dan pengelola tidak boleh menanggung kerugian apapun kecuali diakibatkan dari kesalahan disengaja, kelalaian, atau pelanggaran kesepakatan.

Syarat berikutnya mengenai pengelolaan jenis usaha yang akan di kelola oleh mudharib juga dipersyaratkan serta posisi Bank selaku penyalur dana agar tidak menyalahi ketentuan syariah. pihak pemilik dana maupun pihak Bank Jatim Syariah tidak memiliki hak untuk ikut campur dalam manajemen usaha yang dikelola oleh pengguna dana (mudharib), namun hanya melakukan pengawasan atas jalannya usaha tersebut dan 
Fanni, et al/Jurnal Ekonomi Syariah Teori dan Terapan Vol. 4 No. 1 Januari 2017: 27-43; KESESUAIAN FATWA DSN MUI N0.7/DSN-MUI/IV/2000 DALAM PRODUK PEMBIAYAAN KEPADA KOPERASI UNTUK ANGGOTA (PKPA) DI BANK JATIM SYARIAH CABANG DARMO KOTA SURABAYA

diperbolehkan memberikan saran yang membangun apabila diperlukan sesuai dengan kondisi atau akad yang telah disepakati sebelumnya. Hal tersebut sesuai dengan Fatwa Dewan Syariah Nasional MUI yang menyebutkan bahwa kegiatan usaha oleh pengelola (mudharib), sebagai perimbangan (muqabil) modal yang disediakan oleh penyedia dana, harus memperhatikan hal-hal berikut: (a) Kegiatan usaha adalah hak eksklusif mudharib, tanpa campur tangan penyedia dana, tetapi ia mempunyai hak untuk melakukan pengawasan. (b) Penyedia dana tidak boleh mempersempit tindakan pengelola sedemikian rupa yang dapat menghalangi tercapainya tujuan mudharabah, yaitu keuntungan. (c) Pengelola tidak boleh menyalahi hukum Syari'ah Islam dalam tindakannya yang berhubungan dengan mudharabah, dan harus mematuhi kebiasaan yang berlaku dalam aktifitas itu.

Bentuk pengawasan yang dilakukan oleh Bank Jatim Syariah kepada mudharib (pengelola dana) adalah dengan selalu memberikan evaluasievaluasi yang berkesinambungan, ikut membantu memutuskan pembagian keuntungan dengan persentase yang proporsional, namun apabila mudharib mengalami kerugian pada usahanya, bantuan awal yang diberikan adalah dengan memasukkan tenaga kerja baru ke dalam usaha mudharib yang diharapkan bisa memperbaiki keadaan dan apabila kerugian masih belum bisa diperbaiki baru langkah selanjutnya yaitu memberikan suntikan dana kembali ke pihak mudharib sesuai dengan kesepakatan.

\section{Ketentuan Hukum Pembiayaan Akad Mudharabah}

Menurut Karim (2010: 184), falsafah hukum perjanjian mudharabah ini menampakkan diri dalam bentuk ketentuan-ketentuan pembagian hak dan kewajiban antara pemilik modal (shahibul maal) dan pelaku usaha (mudharib). Salah satu pembagian hak dan kewajiban di dalam mudharabah yang ditentukan para ilmuwan hukum islam klasik adalah bahwa pemilik modal (shahibul maal) tidak diperbolehkan meminta jaminan kepada pelaku usaha (mudharib) atas dana yang diberikan untuk usaha bisnis.

Ketentuan hukum yang pertama adalah mengenai periode pembiayaan yang dilakukan dengan akad mudharabah, menurut penjelasan dari informan penelitian ini didapatkan informasi bahwa Bank Jatim Syariah menjalankan pembiayaan produktif dengan akad mudharabah dengan periode tertentu sesuai dengan kesepakatan kedua belah pihak dan waktu maksimal adalah 5 tahun. Periode tersebut sesuai dengan Fatwa Dewan Syariah Nasional MUI yang menyebutkan bahwa ketentuan hukum pertama dalam pembiayaan mudharabah adalah mudharabah boleh dibatasi pada periode tertentu.

Didalam perjanjian kontrak akad mudharabah tidak diperbolehkan 
Fanni, et al/Jurnal Ekonomi Syariah Teori dan Terapan Vol. 4 No. 1 Januari 2017: 27-43; KESESUAIAN FATWA DSN MUI N0.7/DSN-MUI/IV/2000 DALAM PRODUK PEMBIAYAAN KEPADA KOPERASI UNTUK ANGGOTA (PKPA) DI BANK JATIM SYARIAH CABANG DARMO KOTA SURABAYA

menggunakan kejadian yang belum terjadi atau kejadian dimasa mendatang, menurut infrorman penelitian ini hal tersebut tidak diperbolehkan karena mengingat sesuatu yang belum pasti. Ketentuan yang sudah diterapkan oleh Bank Jatim Syariah ini sudah sesuai dengan yang dipersyaratkan oleh Dewas Syariah Nasional MUI dimana kontrak tidak boleh dikaitkan (mu'allaq) dengan sebuah kejadian di masa depan yang belum tentu terjadi.

Dalam perjalanan menggunakan perjanjian dengan akad mudharabah di Bank Jatim Syariah belum pernah mengalami kerugian, dari laporan keuangan yang diberikan kepada pihak bank, tidak serta merta bank langsung mempercayai. Pihak bank melakukan pengecekan ulang, apabila memang terjadi kerugian pihak bank akan melakukan tindakan seperti memberikan suntikan dana lagi atau solusi lainnya, namun jika terbukti nasabah melakukan penyelewengan atau penipuan maka pihak bank akan menindak tegas nasabah dengan cara melakukan eksekusi terhadap jaminan yang sebelumnya telah diberikan. Penjelasan yang diberikan informan pada penelitian ini sesuai dengan Fatwa Dewan Pengawas Nasional MUI yang menyebutkan dalam mudharabah tidak ada ganti rugi, karena pada dasarnya akad ini bersifat amanah (yad alamanah), kecuali akibat dari kesalahan disengaja, kelalaian, atau pelanggaran kesepakatan.
Informan juga memiliki kesamaan jawaban dimana perselisihan antara kedua belah pihak yang melakukan akad mudharabah ada kemungkinan terjadi, dan apabila terjadi perselisihan tersebut akan dilakukan penindakan tegas secara langsung dari pihak Bank Jatim Syariah, sedangkan pernyataan tersebut tidak sesuai dengan Fatwa Dewan Syariah Nasional MUI yang memberikan ketentuan bahwa jika salah satu pihak tidak menunaikan kewajibannya atau jika terjadi perselisihan di antara kedua belah pihak, maka penyelesaiannya dilakukan melalui Badan Arbitrasi Syari'ah setelah tidak tercapai kesepakatan melalui musyawarah.

Hasil penelitian ini secara keseluruhan Bank Jatim Syariah telah mengimplementasikan sharia compliance pada mekanisme pembiayaan dengan akad mudharabah, hasil penelitian ini sesuai dengan kesimpulan dari penelitianArdhaningsih (2012) dimana kepatuhan syariah akad murabahah sudah dilakukan pada Bank BRI Syariah $\mathrm{KCl}$ Surabaya Gubeng dalam kegiatannya sebagai lembaga keuangan dan lembaga intermediasi. Dalam pelaksanaannya Bank Jatim Syariah cabang Darmo dalam pembiayaan akad mudharabah menggunakan metode menggunakan prinsip 5C dan 7P dalam pembiayaan yang bersifat produktif saja dalam persyaratan kriteria nasabahnya, sesuai dengan hasil penelitian Mirhanifa (2010) bahwa mekanisme pembiayaan mudharabah hanya menerapkan dalam 
Fanni, et al/Jurnal Ekonomi Syariah Teori dan Terapan Vol. 4 No. 1 Januari 2017: 27-43; KESESUAIAN FATWA DSN MUI N0.7/DSN-MUI/IV/2000 DALAM PRODUK PEMBIAYAAN KEPADA KOPERASI UNTUK ANGGOTA (PKPA) DI BANK JATIM SYARIAH CABANG DARMO KOTA SURABAYA

pembiayaan modal kerja dan telah memiliki prosedur yang sistematis dan tertulis yang secara umum menggunakan analisa 5C + 7P dan telah sesuai dengan Fatwa DSN. Pembiayaan mudharabah disalurkan pada jenis usaha produktif.

\section{SIMPULAN}

Berdasarkan pada hasil analisis dan pembahasan penelitian tentang kepatuhan syariah akad mudharabah dalam pembiayaan kepada koperasi untuk anggota (PKPA) berdasarkan Fatwa DSN MUI No. 07/DSN-MUI/IV/2000 di Bank Jatim Syariah Cabang Darmo Kota Surabaya, maka dapat disimpulkan Bank Jatim Syariah telah mengimplementasikan kepatuhan syariah akad mudharabah dalam produk pembiayaan kepada koperasi untuk anggota (PKPA) berdasarkan Fatwa DSN MUI No. 07/DSNMUI/IV/2000 di Bank Jatim Syariah Cabang Darmo Kota Surabaya, karena dalam mekanisme pembiayaan akad mudharabah dalam produk dalam pembiayaan kepada koperasi untuk anggota (PKPA) 2000 di Bank Jatim Syariah Cabang Darmo Kota Surabaya. telah menerapkan Fatwa DSN MUI No. 07/ DSN-MUI/IV/2000, Kepatuhan syariah tersebut dianalisis dari 3 butir yang didalamnya ada beberapa aturan didapatkan dari Fatwa DSN MUI No. 07/ DSN-MUI/IV/2000 yaitu : (1) ketentuan pembiayaan akad mudharabah, (2) rukun dan syarat pembiayaan akad mudharabah, dan (3) ketentuan hukum pembiayaan akad mudharabah

\section{DAFTAR PUSTAKA}

Al Hadist dan Terjemahannya. 1973. Cetakan ke 9. Jakarta: Ikatan Penerbit indonesia

Arifin, Zainul. 2005. Memahami Bank Syariah, Lingkup, Peluang, Tantangan dan Prospek. Jakarta: Alvabet.

Antonio, Muhammad Syafi'i. 2001. Islamic Banking (Bank Syariah Dari Teori ke Praktik). Jakarta: Gema Insani.

AAOIFI. 2002. Accounting and Auditing Standards for Islamic Financial Institution. Bahrain: Manama

Ascarya, dan Diana Yumanita. 2005. Bank Syariah: Gambaran Umum, Seri Kebaksentralan Nomor 14. Jakarta: Bank Indonesia Pusat Pendidikan dan Studi Kebangstrentaralan.

Ascarya, Diana Yumanita, Guruh S. 2009. Rokhimah, Analisis Efisiensi Perbankan Konvensional dan Perbankan Syariah di Indonesia Dengan Data Envelopment Analysis: Current Issues LembagaKevangan Syariah, editor Nurul Huda dan Mustofa Edwin Nasution. Jakarta: Prenada Media Group.

Ayub, Muhammad. 2009. Understanding Islamic Finance. Jakarta : Gramedia Pustaka.

Allen, Franklin dan Anthony M. Santomero. 2010. The Theory of Financial Intermediation.

Al-Qur'an dan Terjemahnya. 2014. Jakarta: Departemen Agama Rl

Ardhaningsih, Ghaniey Septian. 2012. Sharia Compliance Akad Murabahah pada BRI Syariah $\mathrm{KCl}$ SurabayaGubeng. Skripsi Tidak di Publikasikan. Surabaya: Universitas Airlangga.

DSN, Fatwa No . 07. 2000. Pembiayaan Akad Mudharabah (Qardh). Pdf. (http://www.google.com, diakses 17 Agustus 2015).

Gandapradja, Gunadi. 2004. Dasar dan Prinsip Pengawasan Bank, Jakarta: Gramedia Pustaka Utama.

Hasan, Ali, 2003, Berbagai Macam Transaksi Dalam Islam (Fiqh Muamalah), Jakarta: PT Raja Grafindo Persada

Idat, Dhani Gunawan. 2002.Bank dan Lembaga Keuangan Indonesia, Bandung: CV Jemmars.

IFSB. 2009. Guiding Principles on Sharia Governance Systems for Institutions 
Offering Islamic Financial Services. (www.ifsb.org, diakses 17 agustus 2015)

Ikatan Bankir Indonesia. 2014. Memahami Bisnis Bank. Jakarta: PT.Gramedia Pustaka Utama

Kasmir. 2005. Bank dan Lembaga Kevangan Lainnya. Jakarta: PT. Raja Grafindo Persada, Jakarta.

Kasmir. 2006. Dasar-Dasar Perbankan. PT. Raja Grafindo Persada, Jakarta.

Karim, Adiwarman Azwar. 2010. Bank Islam: Analisis Fiqh dan Kevangan. Jakarta: PT. Rajagrafindo Persada.

Keuangan, Otoritas Jasa. 2011. Peraturan Bank Indonesia Nomor 13/2/PBI/2011 Tentang Pelaksanaan Fungsi Kepatuhan Bank Umum. (www.ojk.go.id/en/, diakses 12 Maret 2015).

Keuangan, Otoritas Jasa. 2016. Komposisi Pembiayaan Yang Disalurkan Untuk Bank Umum Syariah dan Unit Usaha Syariah Tahun 20122016.(www.ojk.go.id/en/, diakses 12 Maret 2016).

Mas'adi, Ghufron A. 2002. Fiqh Muamalah Kontekstual. Jakarta: PT. Raja Grafindo Persada.

Miles, B.B., dan A.M. Huberman. 1992. Analisa Data Kualitatif. Jakarta: UI Press

Mirhanifa. 2010. Analisis Mekanisme Pembiayaan Mudharabah pada PT. Bank BNI Syariah Kantor Cabang Medan. Medan: Jurnal Riset Akutansi dan Bisinis Vol 14 No. 1 Universitas Muhammadiyah Sumatera Utara.

Muhammad. $2005 . \quad$ Manajemen Pembiayaan Bank Syari'ah. UPP AMP YKPN, Yogyakarta.

Muhammad. 2006. Manajemen Dana Bank Syariah. Yogyakarta: Ekonisia.

Nazir, Muhammad. 2003. Metodologi Penelitian, Edisi 3. Jakarta : Ghalia Indonesia.

Qur'an in Word Ver 1.3 created by Muhammad Taufiq.

Ryandono, Muhammad Nafik Hadi. 2008. Ekonomi ZISWAQ (Zakat, Infaq, Shadaqah, dan Waqaf). IFDI: Surabaya

Ryandono, Muhammad Nafik Hadi. 2008. Modul disajikan dalam Pelatihan Lembaga Keuangan Syariah. Islamic Finance Development Institute (IFDI). Diolah.

Sabiq, Sayyid. 1988. Fiqih Sunnah (12) \& (13). Al Ma'arif, Bandung.
Siddiqi, Muhammad Nejatullah. 1985. Insurance in an Islamic Economi.

Sudarsono, Heri. 2005. Bank dan Lembaga Keuangan Syariah Deskripsi dan llustrasi. Ekonisia, Yogyakarta.

Sudarsono, Heri. 2008. Bank dan Lembaga Kevangan Syariah. Yogyakarta: Ekonisia.

Sugiyono. 2013. Metode Penelitian Kuantitatif, Kualitatif, dan R\&D, Bandung: Alfabeta.

Sutedi, Adrian. 2009. Perbankan Syariah, Tinjauan dan Beberapa Segi Hukum. Jakarta: Ghalia Indonesia

Syariah, Bank Jatim. Profil Bank Jatim Syariah.

(http://www.bankjatim.co.id/id/syariah /profil, di akses 2 Maret 2016)

Yin, Robert.K. 2009. Studi Kasus Desain \& Metode. Jakarta: PT. Raja Grafindo Persada.

Yudha, Ana Toni Robi Candra. 2010. Jaminan Dalam Akad Pembiayaan Mudharabah Perbankan Syariah di Wilayah Surabaya. Skripsi Tidak di Publikasikan. Surabaya: Universitas Airlangga.

1980. Al-Qur'an Secara Lafzhiyah Jilid I. Jakarta: CV. Tri Burnama Utama.

1980. Al-Qur'an Secara Lafzhiyah Jilid II. Jakarta: CV. Tri Burnama Utama.

1980. Al-Qur'an Secara Lafzhiyah Jilid III. Jakarta: CV. Tri Burnama Utama.

2011. Al-Qur'an. Jakarta: Darul Marifah. 